\title{
The Effect Of The Old Fermentation Of Liquid Organic Fertilizer With Rice Waste On Nitrogen Content, Phosphorus, And Potassium With The Addition Of Human Urine
}

\author{
Fadhilah Achmad $^{1 *}$, Mariani H. Mansyur ${ }^{2}$ \\ 1,2 Departement of Agricultural Technology, Agricultural Technology Faculty, \\ Universitas Cokroaminoto Makassar, Indonesia. \\ * Corresponding author: \\ Email: fadhilah.achmad176@gmail.com
}

\begin{abstract}
.
One source of organic fertilizer that is abundantly available in the environment is urine from humans. Urine is believed to affect the quality of the soil as a plant growing media. In addition, fertilizers are processed from stale rice waste too widely used by farmers in increasing crop productivity. In general, this research was conducted to produce liquid organic fertilizer made from waste rice and human urine. In particular this research implemented to determine the length of fermentation of liquid organic fertilizer made from the best waste of rice and human urine based on chemical content analysis (nitrogen, phosphorus, and potassium) and look for the concentration of waste rice and urine humans are good for fertilization. The stage of this research methodology began by performing a liquid organic fertilizer formulation made from rice waste human urine is added and stored in a closed container for 4, 6, and 8 days then chemical analysis was carried out. The result show that the longer the fermentation of liquid organic fertilizer, the higher the content of $N, P$, and $K$ produced. The 8-day fermentation time with a human urine concentration of $250 \mathrm{ml}$ produced the best content with a nitrogen content of $3.17 \%$, a phosphorus content of $2.68 \%$, and a potassium content of $3.48 \%$. Therefore, it is expected that the use of stale rice waste with the addition of human urine as a source of liquid organic fertilizer which is abundant in everyday life is easier to apply by the community and can contribute to entrepreneurship.
\end{abstract}

Keywords: Organic fertilizer; fermentations; NPK; waste rice; and human urine.

\section{INTRODUCTION}

Optimal plant growth will occur if the plant gets enough nutrients. Common nutrients are available in the form of fertilizers and are easily found in agricultural shops but require a fee to obtain them. One of the obstacles faced in the agricultural sector is the increasingly expensive price of chemical fertilizers. This is because the level of soil fertility is decreasing while the demand for fertilizer use is increasing.Excess use of inorganic fertilizers can leave chemical residues that are harmful to the soil. To overcome this problem, efforts are made to use liquid organic fertilizers that are environmentally friendly to improve soil conditions. Organic fertilizer in the form of manure has been widely used by the community, but the number of livestock that is owned is limited so that the need for fertilizer cannot be met properly. According to Hadisuwito (2012), the advantages of this organic fertilizer are that it is able to quickly overcome nutrient deficiencies, does not have problems in nutrient leaching, and can be directly used by plants. When compared to inorganic fertilizers, liquid organic fertilizers generally do not damage soil and plants even though they are used as often as possible because they do not leave harmful chemical residues that can cause pollution. One source of organic fertilizer that is abundantly available in the environment is urine from humans. Urine is believed to affect soil quality as a medium for growing plants. This is because urine contains the remains of the body's metabolism that can be used as liquid organic fertilizer. The results of chemical urine testing contain substances such as nitrogen waste, vegetable and fruit digestive waste substances, fat metabolism waste products, electrolyte ionions, hormones, toxins, and abnormal substances. 
Therefore, urine can be used as liquid organic fertilizer after fermentation is carried out, because fermentation of urine will break down the organic compounds in urine into nutrients that can be absorbed by plant roots. With the high content of N, P and K elements, urine has a high potential to be used as fertilizer. According to Rofiqoh (2010), one liter of urine can be used to fertilize about one square meter, and by the volume of urine in one year it is estimated that it can be used to fertilize about $300-400 \mathrm{~m}$ of agricultural land. This is obtained by comparing the concentrations used in fertilization with artificial fertilizers. If farmers replace artificial fertilizers with urine, the costs incurred to buy fertilizers can be saved.Apart from fertilizers from human urine, fertilizers from stale rice waste are also widely used by farmers in increasing crop productivity, especially in food crops (rice, corn and soybeans). In everyday life, you can be sure that there is rice left and is not consumed anymore. Stale rice is usually given to livestock, and is sometimes just thrown away in the trash without any further processing until it gradually gives off an unpleasant odor effect on the environment and an unpleasant sight.Based on this, food security and independence are things that must be done to ensure the fulfillment of food needs by utilizing the potential of available resources, so the use of stale rice waste with the addition of human urine as a source of liquid organic fertilizer which is abundant in everyday life is easier to apply by the community and can contribute to entrepreneurship.

\section{MATERIALS AND METHODS}

Research was conducted for 7 months in Makassar. The materials used are rice, human urine, sugar, clean water, and materials used for the analysis of $\mathrm{N}, \mathrm{P}$, and $\mathrm{K}$. This research was prepared based on a completely randomized design (CRD) with $3 \times 3$ factorial pattern with 3 repetitions. The total sampel taken was 27 analyzes. The fermentation time was 4, 6, and 8 days. Concentration of Liquid Organic Fertilizer : $\mathrm{K} 1=250 \mathrm{ml}$ water $+750 \mathrm{ml}$ Urine + rice $+5 \mathrm{sdm}$ sugar $\mathrm{K} 2=500 \mathrm{ml}$ water $+500 \mathrm{ml}$ Urine + rice $+5 \mathrm{sdm}$ sugar $\mathrm{K} 3=750 \mathrm{ml}$ water $+250 \mathrm{ml}$ Urine + rice $+5 \mathrm{sdm}$ sugar

The method of making liquid organic fertilizer uses as much sugar as material 5 spoons, $0.5 \mathrm{~kg}$ of rice that has been stored for 7 days, urine humans who have been stored for \pm 60 days and clean water according to the concentration which have been set. Then the material is put into a jerry can and stirred until evenly distributed then closed tightly according to the fermentation time determined. After the fermentation time is over, the liquid organic fertilizer is opened and filtering then liquid organic fertilizer made from rice waste and human urine is ready for use.

\section{RESULT AND DISCUSSION}

\section{a. $\quad$ Nitrogen $(N)$}

The amount of nitrogen (\%) and its variability showed that the fermentation time of liquid organic fertilizer had a significant effect on the amount of nitrogen. The results of the BNJ test in Table 1 show that the amount of nitrogen with a 4-day fermentation time treatment with a total dose of $750 \mathrm{ml}$ of human urine shows the lowest nitrogen amount (2.68\%) and is significantly different. While the amount of nitrogen with the treatment of 8 days fermentation time with a total dose of $250 \mathrm{ml}$ of human urine showed the highest amount of nitrogen (3.17\%).

Table 1. Average amount of nitrogen (\%) of liquid organic fertilizer with different fermentation time.

\begin{tabular}{lccc}
\hline & \multicolumn{3}{c}{ Long Fermentation } \\
\cline { 2 - 4 } Treatment & 4 days (L1) & 6 days (L2) & 8 days (L3) \\
\hline $250 \mathrm{ml}$ water+750ml urine (K1) & $2,68^{\mathrm{a}}$ & $2,77^{\mathrm{ab}}$ & $2,80^{\mathrm{ab}}$ \\
\hline $500 \mathrm{ml}$ water+500ml urine (K2) & $2,81^{\mathrm{ab}}$ & $2,89^{\mathrm{ab}}$ & $3,17^{\mathrm{b}}$ \\
\hline $750 \mathrm{ml}$ water+250ml urine (K3) & $2,86^{\mathrm{ab}}$ & $2,93^{\mathrm{ab}}$ & \\
\hline
\end{tabular}

Note: Numbers followed by the same letter in the same column mean that they are not significantly different at the Tukey test level of $5 \%$.

The results of statistical analysis show that the longer the fermentation process of liquid organic fertilizer (POC), the higher the nitrogen content produced. This is presumably because in the initial phase (inoculation of bacteria into human urine waste and rice waste) the microbes are still adjusting and carrying 
out metabolism so that their activity increases cell size. Furthermore, cells use carbon from waste as an energy source and reproduce themselves. Decomposition gets better with increasing nitrogen levels on the 8th day. According to Indriani (2011), it is necessary to pay attention to several factors that can affect the quality of fertilizers, including temperature, $\mathrm{pH}$ (degree of acidity), material size, fermentation time, and microorganisms.

The duration of fermentation is one of the important factors in the fermentation process because it is related to the growth phase of microbes which will develop from time to time so that it will affect the content of the products produced. In the research of Thoyib (2016) which used fermentation time of 11, 14, and 17 days, it was seen that the nitrogen content in the largest liquid organic fertilizer at 17 days was around $0.205 \%$ compared to days 11 and 14 . The result of orthogonal polynomial analysis shows that the fermentation time of liquid organic fertilizer is linear, the equation is $y=0.740-1.479 x \mathrm{R}=0.257$. This means that the 8-day fermentation time with a dose of $250 \mathrm{ml}$ of human urine affects the average amount of nitrogen. The relationship between fermentation time and the average amount of nitrogen is presented in Figure 1.

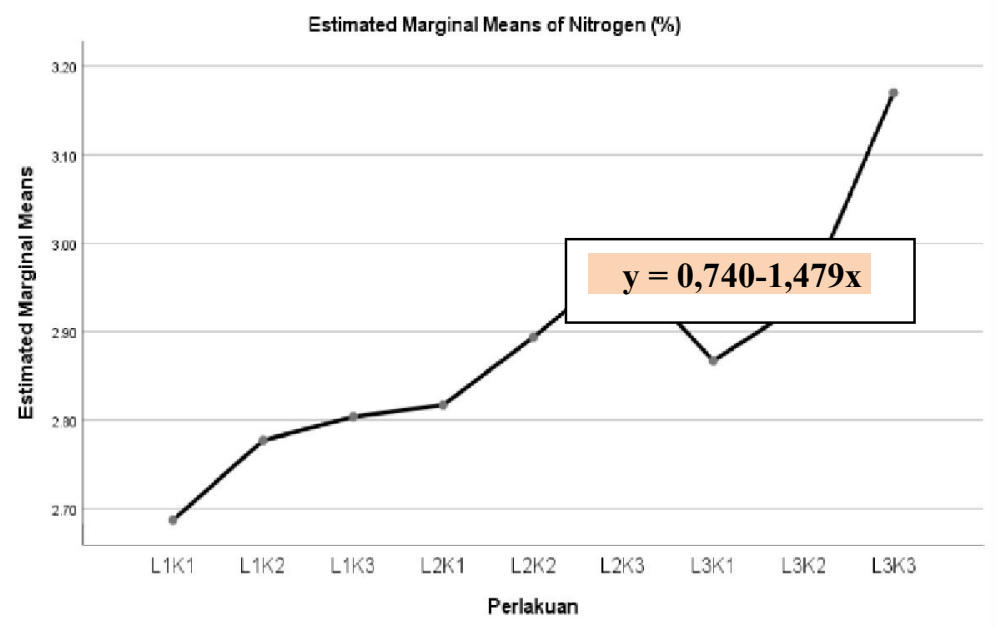

Fig 1. Average amount of nitrogen (\%) liquid organic fertilizer with different fermentation time.

The longer the fermentation with a small dose of organic waste (human urine and rice), the higher the amount of nitrogen content (\%) produced. The main content of organic fertilizers is organic matter, besides that it also has N, P, K nutrients, it's just that the composition of nutrients (substances) contained by organic fertilizers does not remain depending on the material and method of manufacture. Therefore, the factors that are thought to also cause differences in nitrogen content in some samples made from organic waste can be due to the incomplete decomposition process of organic waste (urine and rice)

.In Elvinta's research (2019), it is suggested that the size of the substrate (material) that is not smooth affects the decomposition process. Fermentation time that is too short in the manufacture of liquid organic fertilizers results in immature fertilizer. According to Yuwono (2006), small materials will quickly be decomposed because their surface area increases, thus facilitating the activity of microorganisms. The nitrogen value increases and decreases during the fermentation process. The increase in nitrogen content of organic liquid fertilizers occurs because the decomposition process carried out by microorganisms produces ammonia and nitrogen, the decrease in nitrogen levels is caused by nitrogen reacting with water to form NO3 $^{-}$and $\mathrm{H}^{+}$(Harina, 2018).

\subsection{Phosfor (P)}

The results of the BNJ test in Table 2 show that the amount of phosphorus treated with fermentation time of 8 days with a total dose of $750 \mathrm{ml}$ of human urine shows the lowest amount of phosphorus $(2.49 \%)$. While the amount of phosphorus treated with 6 days fermentation time with a total dose of $250 \mathrm{ml}$ of human urine showed the highest amount of phosphorus (2.68\%).

Table 2. Average amount of phosphorus (\%) liquid organic fertilizer with different fermentation time.

\begin{tabular}{cccc}
\hline & & \multicolumn{4}{c}{ Long Fermentation } \\
\cline { 2 - 4 } Treatment & 4 days (L1) & 6 days (L2) & 8 days (L3) \\
\hline
\end{tabular}




\begin{tabular}{llll}
\hline $250 \mathrm{ml}$ water+750ml urine (K1) & $2,49^{\mathrm{a}}$ & $2,66^{\mathrm{a}}$ & $2,49^{\mathrm{a}}$ \\
\hline $500 \mathrm{ml}$ water$+500 \mathrm{ml}$ urine $(\mathrm{K} 2)$ & $2,56^{\mathrm{a}}$ & $2,50^{\mathrm{a}}$ & $2,62^{\mathrm{a}}$ \\
\hline $750 \mathrm{ml}$ water$+250 \mathrm{ml}$ urine $(\mathrm{K} 3)$ & $2,56^{\mathrm{a}}$ & $2,68^{\mathrm{a}}$ & $2,68^{\mathrm{a}}$ \\
\hline
\end{tabular}

Note: Numbers followed by the same letter in the same column mean that they are not significantly different at the Tukey test level of 5\%.

The amount of phosphorus produced did not have a significant effect on fermentation time and the number of doses of organic waste (human urine and rice). The low phosphorus content in organic liquid fertilizers is thought to be due to the 8-day fermentation time causing microorganisms to absorb phosphorus to carry out their activities. According to Chapelle (2001) states that microorganisms will use phosphorus in the substrate for their metabolic needs during the fermentation process. The low content of phosphorus (P) is also due to the fact that the food reserves used by the decomposing bacteria in the fermentation process have completely reacted, but it is also because the decomposing bacteria has reached a maximum growth condition (a stationary phase that will experience a death phase) before the specified time. This shows that if the fermentation is continued, less yields will be obtained than before (Santi, 2008). The result of orthogonal polynomial analysis shows that the fermentation time of liquid organic fertilizer is linear, the equation is $y=4.058-0.364 \mathrm{x} R=0.070$. This means that the fermentation time of 6 days with a dose of 250 $\mathrm{ml}$ of human urine has no effect on the average amount of phosphorus. The relationship between fermentation time and the average amount of phosphorus is presented in Figure 2.

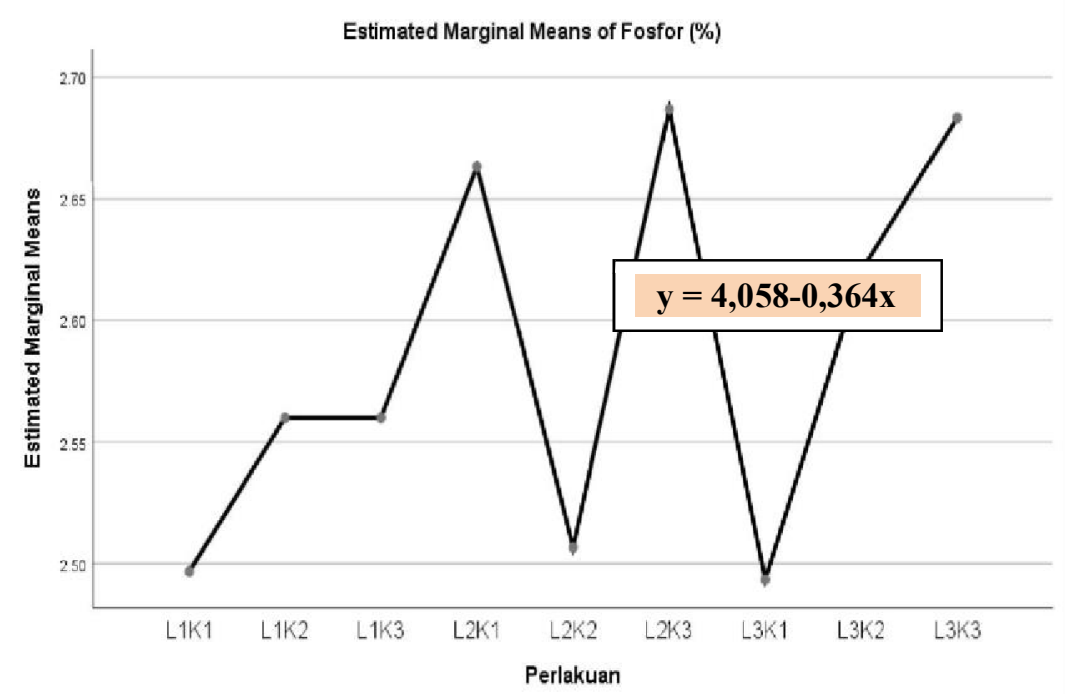

Fig 2. Average amount of phosphorus (\%) of liquid organic fertilizer with different fermentation time.

The duration of fermentation with different dosages of organic waste results in different amounts of phosphorus content, the smaller the number of doses of organic waste, the higher the amount of phosphorus content produced. This is presumably because the concentration of organic waste affects the nutrients of the fertilizer produced, a good organic fertilizer content has a concentration of material (organic waste) that matches the required threshold. If the concentration given is too high, the resulting fertilizer nutrients will be reduced, but if the given concentration is as needed, the fertilizer nutrition will increase. According to Mappanganro N, et al. (2013), giving a high concentration of fertilizer to a certain extent will cause the yield to increase, and at a concentration that exceeds a certain limit it will also cause the yield to decrease and the plants will grow well if the nutrients given are in a balanced and appropriate amount. to the needs of the plant.In a study by Septia (2017) states that the results of the NPK test on fermented and unfermented human urine provide a lower phosphorus content value compared to nitrogen and potassium content. After being applied, the results obtained based on the highest plant height growth were the nutritional treatment of fermented human urine with a concentration of $5 \mathrm{~mL} / \mathrm{L}$ with an average plant height growth of 33.88 . Meanwhile, the lowest average plant height growth was a concentration of $25 \mathrm{~mL} / \mathrm{L}$ with a value of 16.2. According to Nurwahyuni (2012), a concentration that is too high of a given nutrient will get poor results and the nutrition will have a good function if it is used in an optimum amount for plant growth. 


\section{3. $\quad$ Kalium (K)}

The results of the BNJ test in Table 3 show that the amount of potassium with a 4-day fermentation time treatment with a total dose of $500 \mathrm{ml}$ of human urine shows the lowest amount of potassium $(2.93 \%)$ and is significantly different. Meanwhile, the amount of potassium with a long fermentation treatment of 8 days with a total dose of $250 \mathrm{ml}$ of human urine showed the highest amount of potassium (3.48\%).

Table 3. Average amount of potassium (\%) liquid organic fertilizer with different fermentation time.

\begin{tabular}{cccc}
\hline & \multicolumn{3}{c}{ Long Fermentation } \\
\cline { 2 - 4 } Treatment & 4 days (L1) & 6 days (L2) & 8 days (L3) \\
\hline 250ml water+750ml urine (K1) & $3,09^{\mathrm{ab}}$ & $3,15^{\mathrm{ab}}$ & $3,41^{\mathrm{b}}$ \\
\hline $500 \mathrm{ml}$ water+500ml urine (K2) & $2,93^{\mathrm{a}}$ & $3,19^{\mathrm{ab}}$ & $3,46^{\mathrm{b}}$ \\
\hline $750 \mathrm{ml}$ water+250ml urine (K3) & $3,07^{\mathrm{ab}}$ & $3,35^{\mathrm{b}}$ & $3,48^{\mathrm{b}}$ \\
\hline
\end{tabular}

Note: Numbers followed by the same letter in the same column mean that they are not significantly different at the Tukey test level of $5 \%$.

Normal urine has a $\mathrm{pH}$ range between $5-7$ so it can be called slightly acidic. This depends on consumption. Urine is more acidic if you consume lots of protein, conversely for vegetarians the urine will be alkaline. Based on the results of the NPK test in table 1, the pH value is between 6.49-7.63 which means that the urine contains high protein, so that the amount of potassium contained is also high. This is thought to be because potassium plays a role in helping the formation of protein and carbohydrates, so that the higher the protein, the higher the potassium produced. According to Said (2014), the element of potassium functions in helping the formation of protein and carbohydrates, accelerates plant growth, hardens straw and withered wood, increases plant resistance to drought and disease and improves seed / fruit quality. He also added that liquid organic fertilizers which have a $\mathrm{pH}$ (degree of acidity) between 6.5-7.5 will produce a high NPK content. In Hudori's (2007) research on the use of human urine as fertilizer on tomato plants, it was suggested that urine stored for 2 months at room temperature resulted in a high NPK content with a potassium amount of $267.18 \mathrm{mg} / \mathrm{L}$. The result of orthogonal polynomial analysis shows that the fermentation time of liquid organic fertilizer is linear, the equation is $y=2,800-0,679 x \mathrm{R}=0,213$. This means that the fermentation time of 8 days with a total dose of $250 \mathrm{ml}$ of human urine affects the average amount of potassium. The relationship between fermentation time and the average amount of potassium is presented in Figure 3.

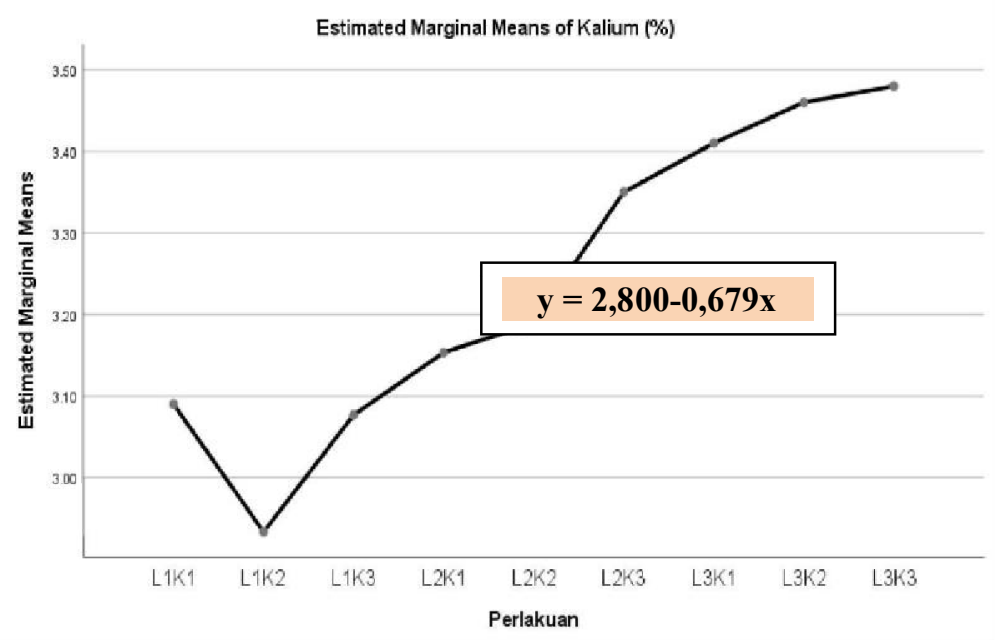

Fig 3. Average amount of potassium (\%) liquid organic fertilizer with different fermentation time.

The longer the fermentation with a small number of doses will produce a high potassium content, while the faster the fermentation with a balanced number of doses will result in a lower potassium content. This is presumably because the fermentation time functions to decompose the organic elements present in the liquid organic fertilizer so that they can be absorbed by the surrounding plants. Mujiatul's research (2013) showed that the length of fermentation affected the levels of N, P, and K contained in tofu waste liquid fertilizer with the addition of Mexican sun plants. The highest levels of $\mathrm{N}, \mathrm{P}$, and $\mathrm{K}$ were obtained from fermentation 4 with $\mathrm{N}$ levels of $732 \mathrm{ppm}$, P levels of $840.6 \mathrm{ppm}$, and K levels of $7189.8 \mathrm{ppm}$. In 
addition, Wahida (2016) also conducted research on liquid organic fertilizers which showed that the NPK content of liquid organic fertilizer from household waste that lasted 14 days with anaerobic fermentation resulted in a nitrogen content of $0.33 \%$, a phosphorus content of $2.98 \%$, potassium content $3.28 \%$, and calcium content $2.66 \%$.

\section{CONCLUSION}

The longer the fermentation of liquid organic fertilizer, the higher the content of $\mathrm{N}, \mathrm{P}$, and $\mathrm{K}$ produced. The 8-day fermentation time with a human urine concentration of $250 \mathrm{ml}$ produced the best content with a nitrogen content of $3.17 \%$, a phosphorus content of $2.68 \%$, and a potassium content of $3.48 \%$.

\section{ACKNOWLEDGEMENTS}

We would like to thank DRPM DIKTI for providing funding to carry out research activities in 2020 . We also thank the Rector of Universitas Cokroaminoto Makassar, Dean of the Faculty of Agricultural Technology, Chair of the Research Institute and Community Services (LPPM) Universitas Cokroaminoto Makassar for all the instructions and assistance in conducting the research.

\section{REFERENCES}

[1] Hadisuwito, S. (2012). Membuat Pupuk Organik Cair. AgroMedia.

[2] Rofiqoh, Y. L., \& Soedjono, E. S. (2010). Studi Potensi Urin Manusia Hasil Composting Toilet Dalam Sistem Ecological Sanitatin (Ecosan). (Studi Kasus: Pusdakota-Ubaya Surabaya). Jurusan Teknik Lingkungan FTSPITS.

[3] Indriani, Y. H. (2011). Membuat Kompos Secara Kilat. Penebar Swadaya. Jakarta.

[4] Thoyib, N., dkk. (2016). Pembuatan Pupuk Organik Cair Dari Sampah Organik Rumah Tangga Dengan Bioaktivator Em4 (Effective Microorganisms). Jurnal Konversi. Volume 5 No. 2.

[5] Elvinta, S. (2019). Pengaruh Lama Fermentasi Pupuk Organik Cair Limbah Cair Tahu dan Daun Lamtoro dengan Penambahan Bioaktivator EM4 terhadap Kandungan Fosfor dan Kalium Total. Skripsi. Fakultas Keguruan dan Ilmu Pendidikan Universitas Sanata Dharma. Yogyakarta.

[6] Yuwono, D. (2006). Kompos Cara Aerob Menghasilkan Kompos Berkualitas. Seri Agritekno. Jakarta.

[7] Harina, S. K. (2018). Pengaruh Lama Fermentasi Pupuk Cair Daun Gamal (Gliricidia sepium) dengan Penambahan Bioaktivator EM4 dan Tetes Tebu terhadap Kandungan N-Total dan Rasio C/N. Skripsi. Fakultas Keguruan dan Ilmu Pendidikan Universitas Sanata Dharma. Yogyakarta

[8] Chapelle, F. H. (2001). Ground-Water Microbiology and Geochemistr. John Wiley and Sons. New York.

[9] S. S., Santi. (2008). Kajian Pemanfaatan Limbah Nilam Untuk Pupuk Cair Organik Dengan Proses Fermentasi. Jurnal Teknik Kimia. Volume 2 No.2.

[10] Mappanganro, N. (2013). Pertumbuhan dan Produksi Tanaman Stroberi pada berbagai Jenis dan Konsentrasi Pupuk Organik Cair dan Urine Sapi dengan Sistem Hidroponik Irigasi Tetes. Jurnal Ilmiah Biologi Biogenesis. Volume 1 No.2.

[11] Septia, P. (2017). Pupuk Urin Manusia untuk Pertumbuhan Kangkung Darat (Ipomoea reptans) dengan Sistem Tanam Hidroponik. Skripsi. Fakultas Teknobiologi Universitas Atma Jaya. Yogyakarta.

[12] Nurwahyuni, E. (2012). Optimalisasi Pekarangan Melalui Budidaya Tanaman Secara Hidroponik. UNDIP Press. Semarang.

[13] Said, I., M. (2014). By product Ternak. IPB Press. Bogor.

[14] Hudori. (2007). Pemanfaatan Urine Manusia Sebagai Pupuk pada Tanaman Tomat. Jurnal Lingkungan Tropis. Edisi Khusus (8): 279-285.

[15] Mujiatul, M. (2013). Peningkatan Kadar N, P, dan K pada Pupuk Cair Limbah Tahu dengan Penambahan Tanaman Matahari Meksiko (Thitonia Diversivolia). Skripsi. Universitas Negeri Semarang. Semarang.

[16] Wahida dan Ni Luh, S., S. (2016). Analisis Kandungan Unsur Hara Pupuk Organik Cair Dari Limbah Rumah Tangga di Kabupaten Merauke. Agricola. Vol.6 (1). 